\title{
PEMANFAATAN INSTAGRAM SEBAGAI MEDIA EKSISTENSI BAGI PEGIAT SENI LETTERING
}

\author{
Mohammad Insan Romadhan ${ }^{1}$, Muchamad Rizqi ${ }^{2}$,Ajeng Ferdiawati ${ }^{3}$ \\ 1,2,3 Program Studi Ilmu Komunikasi, Universitas 17 Agustus 1945 Surabaya \\ Korespondensi: Jalan Semolowaru 45 Surabaya \\ Surel: insanromadhan@untag-sby.ac.id
}

\section{INFO ARTIKEL}

\section{Sejarah Artikel:}

Diterima: 21/12/2020

Direvisi: 16/01/2021

Dipublikasikan: 30/01/2021

e-ISSN: 2721-0995

p-ISSN: 2721-9046

Kata Kunci:

Eksistensi Diri

Instagram

Teori Manajemen Impresi

Seniman Lettering

Keywords:

Self-Existence

Instagram

Impression Management

Theory

Lettering Artists
A B S T R A K Pemanfaatan Instagram sebagai Media Eksistensi bagi Pegiat Seni Lettering. Penelitian ini mengkaji mengenai eksistensi seniman lettering dengan memanfaatkan media sosial Instagram. Peneliti tertarik untuk meneliti citra Nur Awaludin karena rekam jejak dan hasil karya Nur Awaludin yang hampir bisa dijumpai di beberapa tempat. Selain itu tidak banyak orang tahu tentang seniman lettering sedangkan mereka menikmati karya yang dibuatnya. Teori yang digunakan dalam penelitian ini menggunakan teori manajemen impresi diri dari Erving Goffman. Metode yang digunakan dalam penelitian ini menggunakan deskriptif kualitatif dengan teknik pengumpulan data melalui hasil wawancara mendalam dengan informan, observasi, dan dokumentasi melalui media sosial Instagram. Hasil dari penelitian terkait membangun citra Nur Awaludin sebagai seniman lettering menunjukkan bahwa Nur Awaludin memanfaatkan Instagram dengan fitur-fitur yang ada di dalamnya. Nur Awaludin juga menunjukkan kesan-kesan yang baik dan sesuai dengan citra yang dibangun sebagai seniman lettering dengan mengikuti komunitas Subletter dan membuat project team dengan nama Kid Project.

A BSTRACT Utilization of Instagrams as a Medium of SelfExistence on Lettering Arts Activities. This study examines the existence of lettering artists by utilizing Instagram social media. The authors are interested in examining Nur Awaludin's image because Nur Awaludin's track record and works which can be found in several places. In addition, not many people know about lettering artists although they enjoy the work they make. The theory used in this study is the impression management theory from Erving Goffman. The method used in this study is descriptive qualitative data collection technique through the results of in-depth interview with informants, observations, and documentation study through social media Instagram. The results showed that Nur Awaludin used Instagram and its features. Nur Awaludin also showed good impressions and was in accordance with the image that was built as a lettering artist by following the Subletter community and by creating a team project called Kid Project. 


\section{PENDAHULUAN}

Setiap orang memiliki kebiasaan atau keunikan yang ada dalam dirinya. Mulai dari kebiasaan yang biasa dilakukan, kesukaan, keterampilan atau keahlian yang dimiliki, gaya berbicara atau berkomunikasi, cara berpenampilan dan lain-lain. Perbedaan inilah yang menjadikan seseorang dikenal atau diingat oleh orang lain. Setiap individu mempunyai cara tersendiri dalam membuat orang lain mengingatnya, baik itu seorang guru, public figure maupun pekerja seni.

Pekerja seni atau seniman pun beragam, mulai dari seniman bidang drama, tari, musik hingga lukis. Dalam seni lukis, terdapat pula seni tulis indah atau biasa disebut seni lettering. Seni lettering adalah seni yang sekarang ini sedang banyak diminati khususnya kalangan anak muda. Menurut Handoko (2017:1) seni hand lettering adalah seni menggambar huruf. Seni menggambar huruf adalah proses yang diawali dengan membuat sketsa terlebih dahulu, prosesnya dibuat secara manual menggunakan pensil biasa terlebih dahulu. Setelah itu bisa ditambahkan dengan cat, pensil warna, spidol, brush pen, drawing pen, atau yang lainnya.

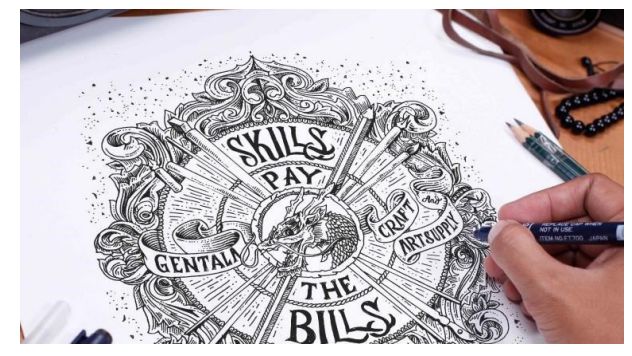

Gambar 1. Seni Lettering

Seorang seniman lettering mempunyai ciri khas tersendiri. Karakteristiknya adalah menggunakan media kertas biasa sebagai alas dalam membuat hand lettering atau sketch book mulai dari sampul bukunya sampai isi buku. Adapun yang membuat hand lettering dengan jenis huruf yang sama atau dengan alas yang lain. Selain itu, hand lettering dapat dibuat lalu diperindah dengan mengedit melalui photoshop.

Meskipun sekarang seni hand lettering sedang banyak diminati tetapi tak banyak orang tahu atau mengenal orang dibalik karya hand lettering tersebut. Mereka hanya menikmati karyanya tanpa tahu siapa yang membuatnya. Selain itu, tak banyak media yang meliput tentang seniman lettering, meskipun ada beberapa media yang meliput tetapi belum banyak yang mengenalkan senimannya. Eksistensi seniman lettering sendiri masih kurang terpublikasi dan masih lebih terfokus pada karyanya saja. Padahal seharusnya seniman dan karya seninya adalah hal yang tidak dapat dipisahkan. Untuk itu perlu adanya suatu upaya yang dilakukan oleh seniman lettering itu sendiri untuk dapat menunjukkan eksistensi dirinya. Salah satu media yang dapat digunakan adalah media sosial Instagram.

Dulu eksistensi diri banyak dilakukan dengan menggunakan media konvensional, seperti melalui surat kabar, radio, majalah, televisi dan lain-lain. Sekarang ini perkembangan teknologi komunikasi berkembang pesat, khususnya media sosial. Eksistensi diri bisa 
melalui jejaring sosial dengan memanfaatkannya melalui Blog, Instagram, dan Youtube. Caranya adalah dengan mengunggah foto dan video kegiatannya. Hal itu juga dilakukan para seniman lettering. Seperti halnya seni lettering yang sedang berkembang dan banyak diminati, perkembangan internet juga sedang banyak diminati, orang-orang memanfaatkan internet guna menunjang semua kebutuhan hidupnya. Mulai dari kebutuhan bersosialiasi dengan kerabat yang sudah lama tidak berjumpa, untuk berpergian dan berlibur, berbelanja atau mencari berbagai kebutuhan. Penggunaan media sosial sudah hampir menjadi makanan sehari-hari semua lapisan masyarakat, mulai dari remaja, dewasa, sampai orang tua.

Eksistensi diri berkaitan dengan citra diri pada pegiat seniman tersebut karena citra diri digunakan untuk menunjang karier seseorang dalam mendapatkan respon positif dari orang lain. Sebenarnya membangun citra diri dapat dilakukan oleh siapa saja, tanpa memandang usia, jabatan yang dimiliki, pekerjaan, ataupun gender sekalipun. Tom Peters (1997) dalam tulisannya yang diterbitkan oleh Fast Company yang berjudul "The Brand Called You" menuliskan antara lain tidak memandang umur, tidak melihat kedudukan, tidak peduli dalam bisnis apa kita berada, kita semua harus memahami betapa pentingnya citra diri. Kita adalah CEO perusahaan sendiri yang disebut Me-Inc (Haroen, 2014). Berdasarkan latar belakang itulah penulis ingin meneliti tentang pemanfaatan Instagram sebagai media komunikasi dalam membangun citra Nur Awaludin sebagai seniman lettering. Selain itu, tujuan dalam penelitian ini adalah untuk mengetahui pemanfaatan Instagram sebagai media eksistensi diri pada pegiat seni lettering.

\section{TINJAUAN PUSTAKA}

Kajian literatur yang digunakan dalam penelitian ini adalah teori manajemen impresi. Teori ini menjelaskan gambaran dari apa di dalam diri seseorang yang ditunjukkan kepada orang lain. Teori ini digagas oleh seorang sosiolog Erving Goffman yang menganggap atau menggambarkan bahwa kehidupan seperti dalam pertunjukkan drama. Situasi yang terdapat di dalamnya adalah panggung drama dan orang yang bermain disebut aktor (Morissan, 2013: 123). Presentasi diri ini dilakukan untuk mengorganisasi tingkah laku individu agar orang lain bisa terkesan dengan individu tersebut. Menurut Goffman (Morissan, 2013:124) presentasi diri sangat tekait dengan pengelolaan kesan. Jadi, presentasi diri dilakukan oleh seseorang agar orang lain memberikan kesan bahwa orang tersebut sangat hebat. Dari sini dapat disimpulkan bahwa peran atau karakter yang dipilih seseorang bukanlah sesuatu yang sepele tetapi betul-betul menentukan diri seorang komunikator ketika ia berhubungan dengan orang lain (Morissan, 2013:125).

Pemaknaan atau kesan yang diberikan individu terhadap penampilan individu bersifat mana suka, situasional dan serba mungkin. Presentasi sosial merupakan peran yang dimainkan seseorang yang terbentuk dari konstruksi sosial dalam interaksi sosial. Menurut Goffman (Kriyantono, 2017:219) proses dari presentasi diri dikenal juga dengan teori impression management. Teori manajemen impresi (impression management) menyebutkan bahwa dalam interaksi sosial setiap individu berupaya menampilkan gambaran dirinya di 
depan orang lain. Karena teori ini terkait langsung dengan cara mempresentasikan diri, maka Rosenfeld, Giacalone \& Riordan (Kriyantono, 2017:220) menyebutnya sebagai teori presentasi diri. Komunikasi digunakan dalam mengelola impresi orang lain terhadap individu (Goffman, 1959). Ada dua bagian di dalamnya, yaitu komunikasi verbal dan komunikasi nonverbal. Karena individu ibaratkan sebagai seorang aktor drama, jadi individu tersebut harus berusaha mengontrol situasi dan isi dari situasi yang melibatkannya. Dalam interaksi sendiri, simbol secara verbal dan nonverbal menghasilkan dua jenis pesan, yaitu expression given on (pesan yang sengaja disampaikan) dan expression given off (pesan yang tidak disampaikan).

Expression given on lebih merujuk kepada simbol verbal dan disebut sebagai wilayah depan, yang dalam pertunjukan drama berarti panggung depan. Wilayah depan atau panggung depan ini berisikan tentang bagaimana individu berpenampilan ataupun bergaya di hadapan orang lain. Biasanya perilaku di panggung depan ini mengikuti aturan-aturan dan norma-norma yang berlaku di masyarakat seperti cara berpenampilan atau berpakaian, cara makan, cara bertingkah laku, dan lain-lain. Wilayah depan atau panggung depan sendiri terdiri dari personal front dan setting. Personal front adalah alat-alat atau perlengkapan yang menunjang individu tersebut dan dianggap khalayak sebagai semua perlengkapan yang harus dimiliki. Setting merupakan situasi fisik yang harus ada ketika individu merencanakan suatu kegiatan atau pertunjukan.

Expression given off biasa disebut sebagai wilayah belakang atau panggung belakang yang menggunakan simbol nonverbal. Expression given off sendiri merujuk pada pesan yang sengaja disembunyikan dari hadapan orang lain. Tapi dimungkinkan masyarakat atau khalayak dapat menerima makna tersebut meskipun individu itu tidak sengaja melakukan atau mengekspresikannya karena untuk mengontrol simbol nonverbal cukup sulit. Panggung belakang ini memungkinkan si aktor untuk menyiapkan diri agar dapat berperan dengan baik di depan orang atau panggung depan.

Dalam teori manajemen impresi ada lima strategi yang bisa digunakan dalam membangun kesan pada publik. Yang pertama, Strategi Ingratiation (menyenangkan orang lain). Biasanya digunakan oleh organisasi yang ingin dipersepsi sebagai pihak yang menyenangkan atau ramah (friendly). Strategi ini diwujudkan dengan menampilkan emosiemosi positif selama interaksi dengan publik, seperti organisasi suka membantu publik dan menghargai kepentingan publik.

Kedua, Strategi Self Promotion (promosi diri). Biasanya digunakan oleh organisasi yang ingin diimpresikan sebagai organisasi yang berkompeten. Strategi ini diaplikasikan dengan menampilkan presentasi yang dicapai organisasi, hal-hal baik yang telah dilakukan organisasi terhadap publiknya, dan menampilkan berbagai penghargaan yang diperoleh organisasi atas prestasinya.

Ketiga, Strategi Exemplification (sebagai contoh). Biasanya digunakan oleh organisasi yang ingin diimpresikan sebagai organisasi yang layak dijadikan contoh atau model bagi organisasi lainnya. Strategi ini terwujud dari beberapa tindakan, seperti mendemonstrasikan 
kemampuan, kelebihan, integritas, dan nilai-nilai organisasi.

Keempat, Strategi Supplication (melemahkan diri). Biasanya digunakan oleh organisasi yang ingin dipersepsi sebagai organisasi yang memiliki keterbatasan dalam membantu publik. Organisasi diimpresikan sebagai pihak yang lemah sekaligus yang menjadi korban dari krisis yang terjadi.

Kelima, Strategi Intimidation (menguatkan diri). Biasanya digunakan oleh organisasi yang ingin dipersepsi sebagai organisasi yang kuat dan mampu mengontrol situasi. Hal ini dapat diwujudkan dengan menampilkan atribut yang mempresentasikan kemarahan atau keinginan untuk menghukum pihak lain yang menyebabkan kerugian.

\section{METODE}

Pendekatan yang digunakan dalam penelitian ini adalah kualitatif. Jenis penelitiannya deskriptif, yaitu penelitian yang hasilnya tidak berupa data statistik ataupun perhitungan angka-angka. Menurut Bogdan dan Taylor (Suwendra, 2018:4) dijelaskan bahwa penelitian kualitatif adalah prosedur penelitian yang menghasilkan data deskriptif berupa kata-kata tertulis atau lisan dari orang-orang dan perilaku yang dapat diamati.

Informan dalam penelitian ini adalah Nur Awaludin sebagai seorang seniman lettering yang memanfaatkan Instagram sebagai media untuk menunjukkan hasil karyanya. Selain itu, informan pendukung yang memperkuat isi penelitian ini adalah Faris. la adalah penggiat seni lettering dan anggota dari komunitas Surabaya Lettering atau Subletter. Tak hanya itu, ada juga kerabat dari informan utama yang juga sesama seniman, yaitu Ahmad Aridho dan yang terakhir ialah klien yang pernah menggunakan jasa dari Nur Awaludin, yaitu Majelis Mie.

Teknik yang digunakan dalam memperoleh dan mengumpulkan data-data yang dibutuhkan dalam penelitian ini adalah melalui observasi, yakni teknik pengumpulan data dengan cara mengamati objek yang diteliti. Wawancara dilakukan peneliti dengan bertanya secara langsung kepada narasumber yang kompeten di bidangnya sesuai dengan penelitian. Dokumentasi digunakan untuk menunjang kelengkapan data-data berupa gambar, foto, dan dokumen-dokumen lainnya.

\section{HASIL DAN PEMBAHASAN}

Seniman lettering membagikan hasil-hasil karya handlettering-nya untuk menunjukkan kesan sebagai seorang seniman lettering dengan memanfaatkan fitur-fitur Instagram. Melalui media sosial Instagram, sejak 2014 Nur Awaludin sudah menetapkan konten yang diusung dalam Instagram. Konten seni terkait lettering adalah konten utama yang diusungnya. Jika melihat secara langsung dari setiap unggahan atau tag foto yang ada di Instagram Nur Awaludin dengan nama akun @awaludin_ akan terlihat dengan jelas konten yang dibuatnya. Hasil karya-karya Nur Awaludin terkait hand lettering juga banyak style dan sering diunggah di akun Instagram miliknya.

Instastory yang sering digunakan orang-orang untuk membagikan unggahan 
selama 24 jam tak luput dari jangkauan Nur Awaludin. Daily life adalah mayoritas yang sering diunggah Nur Awaludin. Pada banyak kesempatan Nur Awaludin sering membagikan kegiatan-kegiatannya melalui instastory. Dari pantauan peneliti, Nur Awaludin memang sering atau bahkan setiap hari membagikan berbagai hal dalam kehidupan sehari-harinya, mulai dari yang terkait keluarganya, foto-foto atau proses saat mengerjakan karyakarya terkait lettering ataupun mural dan juga ketika bersama teman-temannya. Dengan begitu eksistensi dirinya semakin diperjelas dengan unggahannya di instastory. Instastory sering digunakan dalam menampilkan kehidupan sehari-harinya. Oleh karena itu, peneliti mengamati secara langsung instastory yang dibuat Nur Awaludin melalui akun Instagramnya.
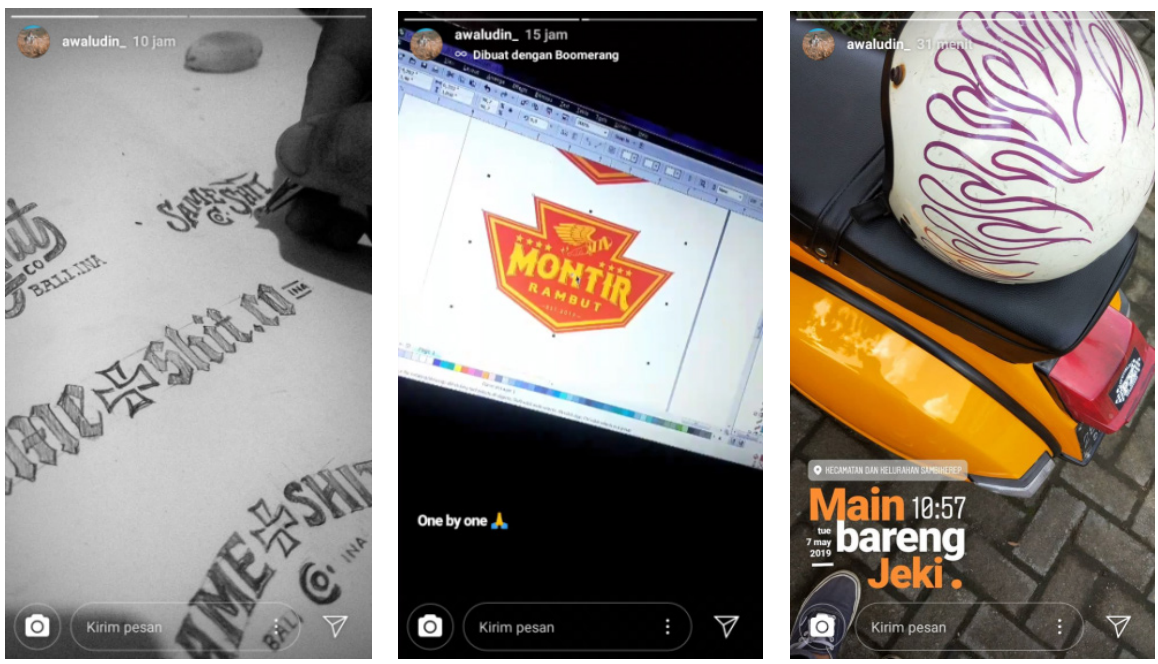

Gambar 2. Instastory Nur Awaludin 2019

Fitur lain yang sering digunakan adalah penggunaan hashtag. Hashtag ini digunakan untuk mempermudah orang-orang dalam melihat foto atau postingan yang dibuat. Dengan tambahan hashtag akan membuat kesan tersendiri di mata orang lain. Dalam membangun citra sebagai seniman, tambahan hashtag juga digunakan untuk mempermudah orang lain untuk melihatnya sebagai seniman karena setiap unggahan terkait karyanya. Hashtag atau tagar digunakan oleh pengguna Instagram untuk mengategorikan sesuai dengan konten yang dibuat. Konten yang digunakan Nur Awaludin dalam Instagram-nya adalah tentang hand lettering. Dalam setiap unggahan terkait karya-karyanya, Nur Awaludin tak jarang menyelipkan hashtag setelah memberikan caption sesuai unggahan yang dibuat. Hashtag tersebut membantu Nur Awaludin agar orang lain bisa melihat hasil karyanya bahkan kepada yang bukan atau belum menjadi pengikutnya di Instagram. Tak jarang pula melalui hashtag tersebut, Nur Awaludin mendapat pujian berupa klik sukai hasil karya lettering Nur Awaludin.

Nur Awaludin tidak pernah lupa menyelipkan hashtag setelah membuat caption seperti \#handlettering \#letteringlogo \#calligraphy \#typegang \#typography. Dengan begitu, selain 
orang-orang yang mengikutinya semakin melihat kekuatan karyanya dengan tambahan hashtag, orang lain yang belum mengikuti Nur Awaludin pun bisa melihat karyanya melalui pencarian dari hashtags tersebut.

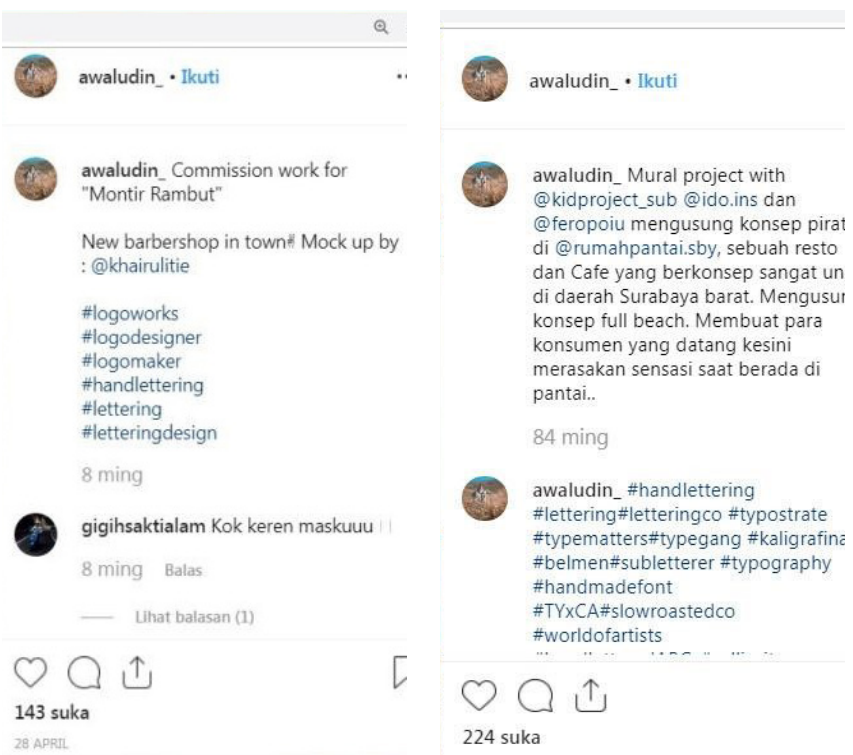

Gambar 3. Hashtag di unggahan Nur Awaludin 2019

Galeri dalam feed juga memengaruhi bagaimana kesan yang dirasakan oleh pengguna Instagram. Ketika feed yang dibuat tertata dengan rapi dan bagus secara visual orang lain akan menyukai dengan sendirinya. Menurut Johansson (Rachmad Kriyantono, 2017:220) upaya ini disebut manajemen impresi, yaitu individu secara sengaja menggunakan komunikasi untuk menciptakan impresi yang diinginkan dari orang lain terhadapnya. Konsistensi Nur Awaludin dalam membuat karya dan penataan feed dalam Instagram membuat feed-nya menjadi lebih rapi dan indah. Style yang sama akan diunggah dengan style yang sama. Karya dengan konsep lettering dengan background warna-warni juga diunggah dengan karya yang selaras pula. Karya secara digital dari foto-foto dengan tambahan lettering juga diunggah dengan karya yang sama pula. Dengan begitu, followers ataupun pengguna Instagram lain yang datang melihat feed dari Nur Awaludin menjadi menyukai feed yang dibuat tersebut.

Menurut pendapat Nur Awaludin, feed dalam Instagram sengaja ditata karena feed sama seperti galeri pribadinya yang bisa dilihat banyak orang sehingga harus disajikan dengan baik. Selain itu, feed yang dibangun Nur Awaludin mampu ditata secara selaras meskipun banyak style yang bisa dibuat. 


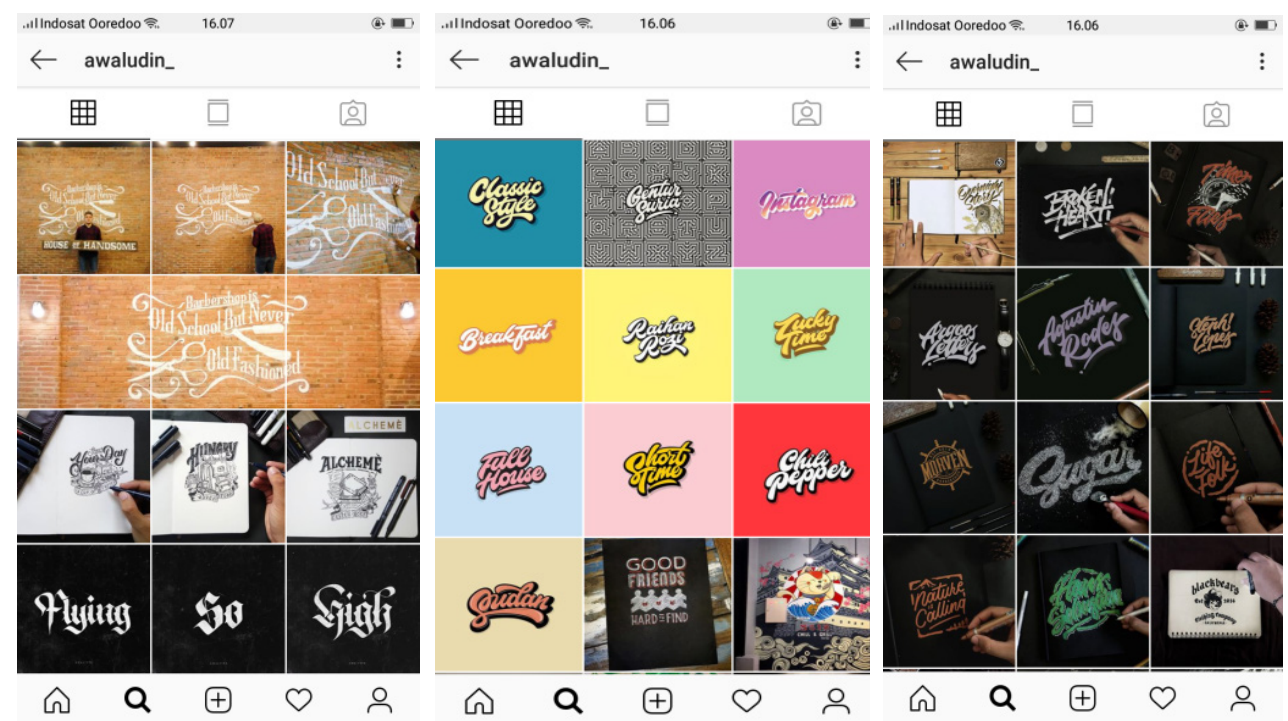

Gambar 4. Feed Nur Awaludin 2019

Hasil unggahannya di akun Instagram @awaludin_sejak awal posting sampai terakhir yang di-update oleh Nur Awaludin terlihat terstruktrur. Hasil karya Nur Awaludin diunggah sesuai dengan tema yang sedang dibuat. Karya lettering secara digital dengan background warna-warni juga diunggah selaras dengan unggahan yang sama dengan background warna-warni. Begitupula dengan hasil karya media paper black, paper white ataupun media tembok sehingga secara visual feed yang dibangun sangat cantik. Nur Awaludin menunjukkan eksistensinya sebagai seniman lettering juga melalui live Instagram. Ketika seseorang mampu menunjukkan karya apa yang sedang dibuat secara langsung membuat eksistensi diri dari seniman tersebut menjadi diakui oleh publik. Segala hal yang relevan dengan apa yang coba dibuat mampu menunjukkan eksistensi di mata orang lain.

Di panggung depannya itu, Nur Awaludin mampu membuat semua orang menjadi terkesan dan menghormatinya sebagai seorang seniman. Sikap seperti rendah hati atau humble, sikap tegas dan tenang serta adanya jiwa kepemimpinan yang ada di dalam dirinya adalah sebagian sikap dan kepribadian yang selalu ditunjukkan oleh Nur Awaludin baik itu ketika sedang bersama dengan teman-temannya di komunitas Subletter ataupun dengan orang lain. Nur Awaludin juga beberapa kali menunjukkan sikap baik hatinya dengan peduli terhadap sesama.

Sebagai seorang seniman, ciri khas sangat penting dimiliki agar mempermudah seseorang mengingatnya. Menurut Mc Nally \& Speak (Dewi Haroen, 2014:13), kekhasan yang dimiliki akan memperkuat eksistensinya sebagai seniman. Secara spesifik, Nur Awaludin tidak memiliki ciri khas tetapi ada sesuatu yang mampu membedakannya dengan seniman lain yang penting untuk ditunjukkan. Sebagai seniman lettering, Nur Awaludin cukup dikenal sebagai seorang seniman yang mampu membuat banyak karya dengan banyak style melalui media selain kertas. Banyaknya style yang mampu dibuat Nur Awaludin ini 
juga sering dibagikan melalui media sosial Instagram-nya. Karena kemampuannya tersebut membuat Nur Awaludin juga dipercaya untuk mengisi atau memberikan ilmu yang dimiliki kepada junior-juniornya dan orang lain melalui kegiatan workshop atau sharing season yang pernah diadakan komunitas Subletter. Kemampuannya mentransfer ilmu melalui workshop ataupun sharing season juga merupakan poin penting.

Berdasarkan teori manajemen impresi yang sudah dijelaskan tersebut, apa yang dilakukan oleh pegiat seni lettering melalui Instagram-nya itu lebih kepada strategi selfpromotion. Melalui media sosial Instagram, sejak 2014 Nur Awaludin sudah menetapkan konten yang diusung dalam Instagram-nya. Konten seni terkait lettering adalah konten utama yang diusungnya. Untuk membuat kesan secara nyata sebagai seniman lettering, Nur Awaludin memanfaatkan live Instagram. Fitur ini merupakan salah satu cara yang tepat digunakan. Ketika seseorang mampu menunjukkan karya apa yang sedang dibuat secara langsung membuat orang lain akan semakin terkesan dengan apa yang dilakukan. Selama Nur Awaludin menggunakan Instagram sebagai media dalam membangun citra, tercatat sering menggunakan live Instagram untuk membagikan kegiatannya ketika sedang mengerjakan karya lettering dan project muralnya.

\section{SIMPULAN}

Pemanfaatan Instagram dengan menggunakan fitur-fitur yang ada seperti memilih konten, melakukan update di instastory, menambahkan hashtag, konsistensi dalam penataan feed dan melakukan live Instagram adalah cara yang dilakukan seniman lettering Nur Awaludin untuk menunjukkan eksistensinya. Sebagai seniman lettering yang juga bagian dalam komunitas Subletter, guna mendukung eksistensinya, Nur Awaludin berusaha menunjukkan bahwa ia memiliki pribadi dan sikap yang rendah hati, tegas, dan terbuka. Kemahiran dalam berkomunikasi, banyaknya style yang mampu dibuat, kepercayaan yang diberikan kepada Nur Awaludin untuk mengisi acara komunitas membuat orang lain terkesan dengan Nur Awaludin sebagai seniman lettering. Strategi tersebut cenderung masuk ke dalam strategi self-promotion.

\section{DAFTAR RUJUKAN}

Albi, A., Johan, S. (2018). Metodologi Penelitian Kualitatif. Sukabumi: CV Jejak

Dini Handoko. (2017). Hand Lettering Islami, Belajar Bahasa Inggris Sambil Berdakwah. Lampung: CV Iqra.

Dewi Haroen. (2014). Personal Branding, Kunci Kesuksesan Anda Berkiprah di Dunia Politik. Jakarta: PT. Gramedia.

Eko sugiarto. (2015). Menyusun Proposal Penelitian Kualitatif: Skripsi dan Tesis. Yogyakarta: Suaka Media.

Esther, M.P (2016). Citra Diri dan Popularitas Artis, Jurnal Dakwah dan Komunikasi Vol. 1 No. 2, 180-201.

Fitrah, Muh., Luthfiyah. (2017). Penelitian Kualitatif, Tindakan Kelas \& Studi Kasus. Sukabumi: CV. Jejak 
Harnas.co (2017, April 17). Hand Lettering, Seni Menggambar Huruf. Di Akses dari http:// www.harnas.co/2017/04/17/handlettering-seni-menggambar-huruf

I Wayan Suwendra. (2018). Metodologi Penelitian Kualitatif dalam Ilmu Sosial, Pendidikan, Kebudayaan dan Keagamaan. Bali: Nilacakra Publishing House.

Morissan. (2013). Teori Komunikasi, Individu Hingga Massa. Jakarta: Prenadamedia Group

Rachmad, Kriyantono. (2014). Teori-Teori Public Relation Perspektif Barat \& Lokal: Aplikasi Penelitian dan Praktik. Jakarta: Kencana.

Riyanto, Theo (2010). Memotivasi Diri, Langkah Menuju Sukses. Yogyakarta: Kanisius

Romadhan, M.I. (2018). Personal Branding Jokowi dalam Mempertahankan Brand Image Melalui Video Blog Youtube. Meta Communication: Journal of Communication Studies, Vol. 3, No. 2

Ropingi el Ishaq. (2017). Public Relation, Teori dan Praktik. Malang: Intrans Publishing 